\title{
POLA PEMANFATAAN SUMBERDAYA LAUT BERBASIS KEARIFAN LOKAL PADA MASYARAKAT WABULA, DI KABUPATEN BUTON ${ }^{1}$
}

\author{
Tamar Mustari, Sulhan Manaf, La Ode Abdul Munafi \\ Universitas Dayanu Ikhsanuddin, Baubau, Sulawesi Tenggara
}

fahmi tamar@yahoo.com

\begin{abstract}
The research describes the patten of utilization of marine resources based on local wisdom in the Wabula community in Buton district. The data were collected by doing interwiews, observation, documentation, and study of literature. Then the data were analyzed descriptively and kualitatively. The results showed that in utilizing marine resources, Wabula community have a local wisdom called kaombo which is protected marine areas by the custom. When a marine area is designated as a kaombo a ban om the explotation of marine resources in the area applies. The prohibition is intended to provide a respite for the continuation of the proliferation of marine biota in kaombo ecosystem. A violation of the prohibition is subject to strict customary law. To preserve the local wisdom of Wabula community in the utilization of marine resources, then through the regulation of Buton Regent Number 13 of 2018, Wabula was designated as an area Customary Law Community in the management of marine resources based om local customary law. The regulation is considered as an ideal model for strengthening local community institutions in conserving marine resources in a sustainable manner.
\end{abstract}

Keywords: patten of utilization of marine resources, local wisdom, fishing communities

\begin{abstract}
Abstrak
Penelitian ini menguraikan pola pemanfataan sumberdaya laut berbasis kearifan lokal pada masyarakat Wabula di Kabupaten Buton. Pengumpulan data dilakukan melalui wawancara, observasi, dokumentasi, dan studi pustaka. Data dianalisis secara deskriptif-kualitatif. Hasil penelitian menunjukkan bahwa dalam memanfaatkan sumberdaya laut, masyarakat Wabula

\footnotetext{
${ }^{1}$ Artikel ini merupakan bagian hasil penelitian kami tentang Pemanfaatan Sumberdaya Alam Pesisir dan Laut di Kecamatan Wabula Kabupaten Buton kerjasama LPPM Universitas Dayanu Ikhsanuddin (Unidayan) Baubau dan Badan Litbang Kabupaten Buton, tahun 2018.
} 
memiliki kearifan lokal yang disebut kaombo, berupa kawasan laut yang dilindungi secara adat. Selama suatu kawasan laut ditetapkan sebagai kaombo, berlaku larangan mengeksploitasi sumberdaya laut dalam kawasan tersebut. Larangan dimaksudkan untuk memberi jeda bagi kelangsungan perkembangbiakan biota laut dalam ekosistem kaombo. Pelanggaran larangan dikenai sanksi tegas adat. Untuk melestarikan kearifan lokal masyarakat Wabula dalam pemanfataan sumberdaya laut, maka melalui Peraturan Bupati Buton Nomor 13 Tahun 2018, Wabula ditetapkan sebagai wilayah Masyarakat Hukum Adat dalam pengelolaan sumberdaya laut berbasis hukum adat setempat. Regulasi ini dipandang sebagai model ideal penguatan kelembagaan masyarakat lokal dalam upaya pelestarian sumberdaya laut secara berkelanjutan.

Kata Kunci: pola pemanfataan sumberdaya laut, kearifan lokal, masyarakat nelayan

\section{PENDAHULUAN}

La $\mathrm{Udu}^{2}$ tidak dapat menutupi rasa penyesalannya ketika mengisahkan pengalaman yang dialaminya di masa muda saat digelandang sejumlah warga kehadapan dewan adat untuk mempertanggungjawabkan perbuatannya. Ia tertangkap tangan tengah memancing ikan dalam kawasan laut yang secara adat ditetapkan sebagai kaombo. Akibat perbuatannya, La Udu dijatuhi sanksi adat berupa denda serta penyitaan alat tangkap dan hasil tangkapannya.

Akan halnya dengan La Adi (nama disamarkan), yang beberapa tahun silam, juga pernah mengalami pengalaman dikenai sanksi adat. Sanksi atas dirinya dijatuhkan dewan adat karena ia dituduh menjaring ikan dalam kaombo. Namun, dihadapan dewan adat, La Adi menyangkal tuduhan tersebut. Ia berdalih, ikan hasil tangkapannya dijaring di luar kaombo. Meski sejumlah warga membeberkan kesaksian yang membuktikan perbuatannya, karena bukan kali pertama ia dicurigai

\footnotetext{
${ }^{2}$ Untuk menunjung etika penelitian, nama informan disamarkan.
}

mengambil hasil laut dalam kaombo, namun La Adi bersikukuh tidak mengakui kesalahannya. Akibat perbuatannya, ia dijatuhi sanksi adat berupa pengucilan dari lingkungan sosial. Selama sanksi berlangsung, La Adi merasakan betul penderitaan karena warga dilarang berinteraksi dengannya. Sanksi adat atas dirinya dicabut beberapa bulan kemudian setelah ia mengakui kesalahannya dihadapan dewan adat dan menyatakan permintaan maaf kepada masyarakat.

Penelitian ini dimulai dengan mengangkat narasi tentang La Udu dan La Adi, dua nelayan Wabula yang pernah mengalami pengalaman dijatuhi sanksi adat karena melakukan tindakan yang tergolong destruktif pada kawasan laut yang secara adat ditetapkan sebagai kaombo. Dalam konsepsi masyarakat Wabula, kaombo adalah kawasan perlindungan laut (marine procted area). Dalam kaombo berlaku larangan adat mengeksploitasi sumberdaya laut3.

\footnotetext{
${ }^{3}$ Larangan mengeskploitasi sumberdaya laut dalam kaombo identik dengan praktik sasi di Maluku. Namun, dalam bahasa Buton terdapat kata sasi yang berarti "larang". Apakah ada korelasi antara sebutan sasi dalam bahasa Buton dengan praktik sasi di Maluku kiranya perlu penelitian khusus, mengingat kelompok masyarakat nelayan di Maluku
} 
Dalam praktik konservasi tradisional sumberdaya laut di Wabula, larangan dimaksudkanuntukmemberikesempatan bagi kelangsungan perkembang-biakan biota laut serta lingkungan ekosistemnya sebagi kawasan yang dilindungi secara adat. Pelanggaran terhadap larangan dikenai sanksi tegas adat sebagaimana pernah dialami La Udu dan La Adi.

Sebagaimana lazimnya dalam studi etnografi, pengalaman kedua nelayan tersebut di atas menjadi entry point untuk memasuki detak jantung kehidupan masyarakat Wabula dalam pemanfataan sumberdaya laut berbasis kearifan lokal yang mereka miliki. Kearifan lokal tersebut disarikan dari pengalaman bersama mereka dalam berinteraksi dengan lingkungan laut. Kearifan lokal kebaharian di Indonesia telah menjadi topik perbincangan menarik dan mendesak kepentingannya sehubungan dengan isu program rehabilitasi dan pengelolaan lingkungan ekosistem laut. Kearifan lokal masyarakat nelayan dipahami sebagai pengetahuan budaya (cultural knowledge) yang mencakup nilainilai, norma-norma, dan kepercayaankepercayaan yang melandasi perilaku budaya (cultural behavior) masyarakat nelayan dalam memanfatkan sumberdaya lingkungan laut secara berkelanjutan (Tang, 2007:139).

Bentuk kearifan lokal tersebut dapat berupa aturan yang membatasi perilaku penangkapan, aturan yang membatasi penggunaan alat tangkap tertentu, dan dapat pula berbentuk penutupan total sebuah lokasi (Neil, 2007:127). Sejumlah hasil studi menunjukan bahwa kearifan lokal masyarakat nelayan menjadi instrumen yang fungsional dalam menjaga dan mempertahankan kelangsungan hidup biota perairan laut serta lingkungan ekosistemnya (Raodah dkk, 2017; Evawarni, 2017). Penelitian ini bertujuan mengungkapkan pola pemanfataan sumberdaya laut berbasis kearifan lokal tradisional Wabula sebagai bagian dari upaya memahami sisi humanis kehidupan masyarakat bahari di tengah maraknya praktik eksploitasi sumberdaya laut yang makin destruktif dewasa ini.

\section{METODE}

Penelitian dilakukan di wilayah Kecamatan Wabula Kabupaten Buton. Masyarakat di Kecamatan Wabula umumnya berprofesi sebagai nelayan dan masih memegang teguh sejumlah aturan adat yang berhubungan dengan prinsipprinsip konservasi tradisional dalam pemanfaatan sumberdaya laut. Penelitian dilakukan secara kualitatif melalui pendekatan etnografi. Pengumpulan data lapangan dilakukan melalui wawancara, observasi, dan dokumentasi. Subjek penelitian adalah nelayan, pemangku adat, tokoh masyarakat, serta aparat pemerintah setempat. Data dianalisis secara deskriptif-kualitatif.

\section{HASIL DAN \\ PEMBAHASAN \\ SETTING LOKASI, PENDUDUK, DAN MATA PENCAHARIAN}

Secara tradisional, Wabula terletak pada kawasan pale sukanaeo yakni bentangan wilayah disebelah barat pusat Kesultanan Buton. Dalam sistem 
pemerintahan Buton tradisional, Wabula bersama Wasuemba berada dalam pembinaan pejabat pusat Kesultanan Buton yakni bontona peropa. Dalam menjalankan urusan pemerintahan lokal (kadie) pada masa lalu, Wabula memiliki perangkat sara kadie ${ }^{4}$, terdiri dari 1 pejabat parabela dan 6 pejabat wati (Zahari, 1977:110).

Seiring pembentukan desa dan kecamatan di Kabupaten Buton, wilayah adat Wabula kemudian dimekarkan menjadi beberapa desa. Nama Wabula pun diabadikan menjadi nama desa, yakni Desa Wabula dan Desa Wabula I, bahkan menjadi nama salah satu kecamatan di Kabupaten Buton yang wilayah administratifnya mencakup wilayah tradisional Wabula. Kini, wilayah Kecamatan Wabula terdiri atas tujuh desa. Selain Desa Wabula dan Wabula I, desa-desa lainnya adalah Wasuemba, Holimombo, Koholimombona, Wasampela, dan Bajo Bahari. Ketujuh desa tersebut memiliki karakteristik sebagai desa pantai.

Kecamatan Wabula memiliki luas $51,58 \mathrm{~km} 2$ dan berada pada garis antara 122,320-122,400 BT dan antara 5,1405,300 LS. Wilayahnya berbatasan dengan (i) ibukota Kabupaten Buton (Pasar Wajo) di sebelah utara, (ii) Laut Banda di sebelah selatan dan timur, dan (iii) Kabupaten Buton Selatan di sebelah barat. Sebagai wilayah pesisir, Wabula memiliki sumberdaya lingkungan laut, baik sumberdaya perikanan, terumbu karang, hutan bakau (mangrove), padanglamun, maupun sebagai kawasan potensial untuk pengembangan destinasi pariwisata bahari di Kabupaten Buton. Potensi lingkungan pesisir dan laut Wabula secara umum masih tergolong baik. Bahkan, disejumlah kawasan tertentu berlangsung penanaman mangrove oleh warga setempat.

Ekosistem terumbu karang di Wabula mencapai luas 554,2 ha., dan merupakan kawasan ekosistem terumbu karang terluas di Kabupaten Buton. Habitat terumbu karang di wilayah itu di dominasi karang hidup, yang berkisar antara 30-61 \%. Wabula juga memiliki hutan mangrove yang tumbuh pada areal seluas 49,4 ha. Sedangkan ekosistem padang lamun mencapai luas 709,8 ha., dan merupakan kawasan ekosistem padang lamun terluas di Kabupaten Buton.

Hingga tahun 2018, penduduk Kecamatan Wabula berjumlah 6.211 jiwa, terdiri dari 3.105 penduduk lakilaki dan 3.106 penduduk perempuan, dengan tingkat kepadatan 120 jiwa/ $\mathrm{km}^{2}$. Sejak awal, masyarakat Wabula hidup dari sektor ekonomi perikanan laut disamping sektor ekonomi darat. Sektor ekonomi perikanan laut digeluti masyarakat melalui profesi sebagai nelayan, baik nelayan tetap maupun sebagai nelayan sambilan. Berdasarkan persentase jumlah kepala keluarga (KK), masyarakat Wabula yang berprofesi sebagai nelayan tetap hingga tahun 2018 berjumlah 343 KK $(87,05 \%)$ dan sejumlah 51 KK (12,95\%) adalah nelayan sambilan.

Perikanan skala kecil merupakan jumlah terbesar dari seluruh armada perikanan di Wabula. Jenis armada penangkapan ikan di dominasi perahu 
tanpa motor. Hingga tahun 2018, armada tangkap jenis ini berjumlah 209 unit. Seiring adaptasi motorisasi armada tangkap, sebagian nelayan Wabula kemudian menggunakan perahu motor inboard. Hingga tahun 2018, armada tangkap jenis ini terbagi dalam dua tipe, yakni perahu motor inboard berkekuatan < 5 gt sejumlah 161 unit dan perahu motor inboard berkekuatan 5-10 gt sejumlah 2 unit. Selain itu juga terdapat armada tangkap jenis perahu motor outboard. Hingga tahun 2018, armada tangkap jenis ini berjumlah 7 unit. Kondisi armada tangkap yang masih didominasi perahu tanpa motor menjadi salah satu determinan rendahnya hasil produktivitas nelayan. Jenis alat tangkap yang umum digunakan nelayan setempat juga beragam. Hingga tahun 2018, jenis alat tangkap yang digunakan nelayan setempat terdiri dari jenis pancing layang (258 unit), pancing tonda (268 unit), jaring insang (205 unit), pancing rawai (183 unit), pengait (114 unit), sero (36 unit), dan bubu (16 unit).

Akses nelayan Wabula dalam pemanfataan sumberdaya perikanan laut tidak terjadi sepanjang tahun, terutama ketika berlangsung musim timur (MeiSeptember). Dalam musim ini, pekerjaan alternatif yang digeluti keluarga nelayan adalah industri rumah tangga berbasis hasil laut. Jenis usaha ini umumnya dilakukan kaum perempuan melalui pembuatan ikan kering, baik jenis ikan asin maupun ikan asap. Aktifitas melaut untuk menangkap ikan berlangsung pada bulan Desember-Februari. Sepanjang musim ini, pada waktu bulan terang, nelayan setempat umumnya melaut sehari penuh, dengan pola "pergi pagi- pulang sore". Sedang, pada saat bulan gelap, mereka melaut dengan pola "pergi sore-pulang pagi".

Meskipun lingkungan perairan laut Wabula kaya dengan potensi perikanan namun usaha budidaya ikan dan rumput laut belum dapat berkembang maksimal. Hal ini disebabkan terbatasnya penguasaaan teknologi budidaya oleh masayarakat setempat. Kecuali itu, minimnya prasarana pasca panen, akses pasar, serta akses permodalan dalam mendukung kegiatan usaha kenelayanan juga berakibat pada belum maksimalnya pengembangan agrobisnis di sektor perikanan laut.

\section{Pemetaan Lingkungan Laut dan Pola Pemanfataan Sumberdaya}

Kearifan lokal tradisional dalam pemanfataan sumberdaya laut pada masyarakat Wabula tidak dapat dipisahkan dengan pemahaman mereka tentang lingkungan laut. Dalam sistem pengetahuan setempat, lingkungan laut dibagi atas dua kawasan, yakni pangkolo dan nambo. Pangkolo adalah lingkungan laut yang berada dalam batas-batas darat, dan merupakan habitat ekosistem mangrove. Pangkolo merupakan kawasan penghubung antara ekosistem darat dan ekosistem laut. Sedangkan, nambo adalah lingkungan yang meliputi perairan pantai dan laut-dalam.

Dalam hubungannya dengan pemanfaatan sumberdaya lingkungan laut, nambo dibedakan atas dua kawasan, yakni: (i) kawasan perairan pesisir pantai dan laut-dalam yang dilindungi, dan (ii) kawasan perairan pesisir pantai dan lautdalam sebagai area fishing ground (daerah eksploitasi). Pembagian nambo dalam 
dua kawasan merefleksikan pemetaan lingkungan laut yang berkorelasi dengan pola pemanfaatan sumberdaya laut secara berkelanjutan.

Dalam pemenuhan kebutuhan ekonomi rumah tangga, nelayan tradisional Wabula umumnya masih tergantung pada ketersediaan biota perairan pesisir dan laut. Menangkap ikan dan mencari kerang merupakan aktifitas pokok sehari-hari mereka. Dalam sebuah rumah tangga nelayan, selain kepala keluarga, anak laki-laki yang sudah remaja umumnya turut membantu orang tua melakukan pekerjaan sebagai nelayan. Ibu rumah tangga pun turut membantu pekerjaan suami, menjual ikan hasil tangkapan ke pasar atau membuat produk ikan kering. Realitas ini menunjukan bahwa ketersediaan sumberdaya laut, khususnya ikan dan biota perairan pesisir lainnya menjadi jaminan ketahanan pangan (food securiy) bagi nelayan setempat.

Meskipun

memanfaatkan sumberdaya laut sebagai sumber kehidupan namun mereka tidak dibolehkan mengeksploitasinya secara berlebihan, termasuk menggunakan alat tangkap yang tidak ramah lingkungan. Karena, pemanfataan sumberdaya laut, secara tradisional, diatur melalui adat setempat. Adat dalam konsepsi antropologis dipahami sebagai suatu kebiasaan yang terwariskan secara turun temurun oleh anggota masyarakat dan berfungsi menata hubungan-hubungan kemasyarakatan demi tercipta dan terpeliharanya hubungan fungsional di antara masyarakat, termasuk hubungan timbal balik antara manusia dengan lingkungannya. Dalam praktik konservasi dan pemanfataan sumberdaya laut di Wabula terdapat suatu sistem adat yang relevan, yakni kaombo. ${ }^{5}$

Dalam konsepsi masyarakat Wabula, kaombo adalah kawasan laut, yang dalam waktu tertentu atau selamanya, berlaku larangan mengeksploitasi jenis biota tertentu atau keseluruhan jenis biota yang terdapat di dalam kawasan. Dalam praktik konservasi dan pemanfataan sumberdaya laut, kaombo merupakan kawasan perlindungan laut (marine procted area) yang ditetapkan untuk menjamin kelangsungan hidup biota perairan laut serta lingkungan ekosistemnya secara berkelanjutan. Pola pemanfataan sumberdaya laut berbasis kearifan lokal kaombo sekaligus dimaksudkan untuk menghindarkan laut sebagai wilayah open access. Sistem kaombo dalam pemanfataan sumberdaya laut merefleksikan konsep pemilikan bersama (communal property right) atas sumberdaya laut sekaligus pelembagaan pemilikan bersama itu sebagai milik komunal masyarakat setempat. Konsep sumberdaya milik bersama, yang secara tradisional diatur oleh sara merupakan dasar hak ulayat laut, tanah, maupun hutan di Buton (Hanan, 2010).

Sebagai kawasan laut yang dilindungi secara adat, kaombo dibedakan atas dua kawasan, yakni kaombo saumuru dan kaombo awaktuu. Kaombo saumuru merupakan kawasan laut yang ditutup secara permanen dari aktifitas eksploitasi.

\footnotetext{
${ }^{5}$ Sistem kaombo sebagai pranata kearifan lokal dalam pemanfaatan sumberdaya laut di Wabula juga dipraktikan dalam sistem pengelolaan hutan pada umumnya di Buton. Pemanfaatan sumberdaya hutan dalam kaombo, semisal kayu, hanya dibolehkan untuk keperluan kolektif masyarakat setempat semisal untuk keperluan membangun mesjid, balai pertemuan adat, dan sebagainya (Munafi, 2007).
} 
Kawasan laut seperti ini umumnya dikeramatkan, dipandang angker, dan menakutkan. Selain karena lautnya yang dalam, juga dipandang sebagai tempat hunian berbagai jenis hewan dan hantu laut yang dapat membahayakan keselamatan manusia. Karena itu, dalam kaombo saumuru berlaku pepali (pemali), yakni larangan melakukan eksploitasi sumberdaya laut. Larangan juga merefleksikan rasa hormat manusia pada laut. Ini dipahami, karena bagi masyarakat Wabula, laut dipandang sebagai sumber kehidupan. Rasa hormat pada laut juga terefleksi melalui larangan mengucapkan kata-kata kotor, takabur, atau berbicara tidak sepatutnya di laut. Mereka meyakini, pelanggaran terhadap larangan berakibat pada terjadinya malapetaka laut, seperti badai dan ombak besar atau tidak memperoleh rezeki laut.

Perilaku manusia terhadap lingkungan melalui tindakan yang bercorak mistis dan magis sebagaimana terefleksi melalui larangan pemanfataan sumberdaya laut dalam kaombo saumuru dipahami sebagai strategi kebudayaan. Setiap kebudayaan berisi sistem nilai yang berfungsi mengatur secara khusus perangkat-perangkat tindakan manusia, baik individu maupun kelompok, yang didasarkan pada pandangan dan nilainilai budaya yang dianut (Lampe, 2008). Dalam hubungannya dengan pola pemanfataan sumberdaya laut di Wabula, larangan mengeskploitasi sumberdaya laut dalam kaombo saumuru dipahami sebagai instrumen budaya yang secara fungsional dimaksudkan untuk: (a) melindungi kawasan laut tertentu sebagai tempat pemijahan ikan, (b) menjaga habitat biota perairan laut yang tergolong endemik, dan (c) menjaga keanekaragaman biota perairan laut serta ekosistemnya dari ancaman kerusakan dan kemerosotan populasi.

Berbeda dengan kaombo saumuru, maka kaombo awaktuu adalah kawasan laut yang "ditutup" atau "dibuka" pada waktu-waktu tertentu. Dalam praktiknya, ketika salah satu kawasan laut dinyatakan ditutup (di kaombo), maka pada kawasan laut tertentu lainnya dinyatakan terbuka (bongkaana kaombo) sehingga nelayan dapat memanfaatkan hasil laut di wilayah tersebut. Siklus pemanfataan sumberdaya laut melalui sistem kaombo awaktuu dimaksudkan untuk memberi kesempatan biota laut serta lingkungan ekosistemnya dapat membaharui diri dan berkembang biak secara berkelanjutan. Kawasan laut yang ditetapkan sebagai kaombo awaktuu umumnya berada di wilayah perairan pesisir.

Dalam tradisi setempat, penetapan suatu kawasan laut sebagai kaombo awaktuu diawali musyawarah sara. Dalam musyawarah dibicarakan halhal sebagai berikut: (i) penetapan batasbatas kawasan laut yang akan di kaombo (ditutup sementara) untuk jangka waktu tertentu, (ii) penetapan jenis-jenis biota laut yang tidak boleh diekploitasi selama kawasan laut tersebut ditetapkan sebagai kaombo, dan (iii) sanksi terhadap tindakan destruktif dalam kaombo. Setelah ketentuan-ketentuan tersebut dimufakati selanjutnya dilakukan pemasangan tanda batas kaombo awaktuu oleh wati selaku perangkat sara yang membidangi tugas tersebut. Secara tradisional, tanda batas yang umumnya digunakan sebagai penanda kaombo awaktuu adalah batang kayu yang ditancap ke laut dan dipasangi daun kelapa. Pemasangan tanda batas 
kaombo dilakukan dalam sebuah ritual adat. Dalam ritual diumumkan peringatan kepada masyarakat untuk tidak mengambil hasil laut selama kawasan tersebut di kaombo. Pelanggaran larangan dikenakan sanksi tegas adat. Pengawasan kaombo dilakukan oleh masyarakat setempat. Namun, secara khusus tugas tersebut menjadi tanggungjawab pejabat adat yang disebut sumukanoombo. Pengawasan kaombo sangat penting guna mencegah pencurian sumberdaya laut maupun tindakan destruktif lainnya dalam kaombo, baik oleh nelayan setempat maupun nelayan dari luar Wabula.

Kawasan laut yang ditetapkan sebagai kaombo awaktuu pada masa lalu adalah Topa dan Lahunduru (Mustari dkk, 2016). Kawasan laut Topa terletak disebelah utara Wabula, sedangkan kawasan laut Lahunduru terletak di bagian selatan. Kedua kawasan laut itu secara bergantian ditetapkan menjadi kaombo awaktuu. Jangka waktu sebuah kawasan laut ditetapkan sebagai kaombo awaktuu berkisar antara enam hingga duabelas bulan. Penetapan jangka waktu tersebut dimaksudkan agar biota laut beserta lingkungan ekosistemnya dapat membaharui diri secara berkelanjutan.

Semula, larangan memanfaatkan hasil laut dalam kaombo awaktuu tidak diberlakukan pada semua jenis biota laut. Larangan terbatas pada jenis biota ikan, sementara biota laut lainnya seperti kerang-kerangan dapat dimanfaatkan masyarakat setempat untuk pemenuhan kebutuhan hidup mereka. Meski demikian pemanfataan biota tersebut hanya boleh dilakukan dengan peralatan tangkap tradisional, seperti pancing, tombak, bubu, dan jala berukuran kecil. Dalam perkembangannya, larangan tidak lagi sebatas pada biota ikan tetapi juga terhadap beberapa jenis biota laut lainnya, seperti teripang, lola, dan japingjaping. Selain karena pertimbangan ekonomis, larangan ini juga didasarkan pada pertimbangan ekologis. Hal ini dipahami, karena ketiga jenis biota yang disebut terakhir disamping memiliki nilai ekonomi yang relatif mahal, sehingga selalu menjadi incaran nelayan, juga dimaksudkan untuk mencegah kemerosotan populasi. Dengan demikian larangan eksploitasi lebih didasarkan pada pertimbangan kelestarian. Pola pemanfataan sumberdaya laut melalui sistem kaombo, baik saumuru maupun awaktuu, yang dipraktikan masyarakat Wabula secara fungsional mendukung kelestarian sumberdaya lingkungan laut secara berkelanjutan.

\section{Sanksi Adat}

Larangan pemanfaatan sumberdaya laut dalam kaombo sebagaimana diuraikan di atas disarikan dari nilai-nilai yang dibangun dan dijunjung bersama oleh warga masyarakat Wabula, yang mereka warisi dari leluhur. Nilai-nilai tersebut berfungsi sebagai pedoman, pengontrol, dan rambu-rambu bagi masyarakat dalam memanfaatkan sumberdaya laut secara berkelanjutan. Larangan pemanfaatan sumberdaya laut dalam kaombo, baik saumuru (permanen) maupun awaktuu (sementara) merupakan aturan adat yang dipatuhi bersama oleh warga masyarakat setempat. Aturan adat tersebut kemudian menjadi dasar pemberian sanksi adat kepada pihak yang melanggarnya.

Beberapa praktik pemanfataan sumberdaya laut yang digolongkan sebagai pelanggaran adat di Wabula adalah: (i) mengambil biota laut tertentu 
atau semua jenis biota pada suatu kawasan laut yang ditetapkan sebagai kaombo (saumuru atau awaktuu), dan (ii) penggunaan alat tangkap yang tidak ramah lingkungan, seperti bahan peledak, bius, pukat harimau, dan kompresor sebagai alat bantu selam ketika mengambil hasil laut.

Institusi yang memiliki otoritas tradisional menjatuhkan sanksi adat adalah sara, yakni dewan adat setempat. Sara dipimpin seorang pejabat adat yang disebut parabela. Sanksi adat dapat berupa penyitaan alat tangkap dan hasil tangkapan, denda, hingga pengucilan pelaku dari lingkungan sosial. Pada masa lalu, denda yang dikenakan kepada pelanggar adat adalah membayar uang sejumlah 4 bhoka yang diserahkan kepada dewan adat. Jika denda tidak dapat dibayar, kewajiban tersebut menjadi hutang keturunan pelaku. Penegakan sanksi adat sebagai bagian dari sistem pengelolaan sumberdaya laut berbasis kearifan lokal tradisional kaombo secara fungsional meminimalisir praktik destruktif dalam pemanfataan sumberdaya laut di Wabula.

Sungguh pun demikian, seiring transformasi masyarakat, otoritas adat yang semula menjadi mekanisme regulasi pemanfataan sumberdaya laut di Wabula, secara perlahan mengalami pengikisan menyusul pengambil alihan pengelolaan wilayah laut oleh pemerintah melalui introdusir berbagai paket regulasi di sektor perikanan dan kelautan. Akibatnya, penanganan kasuskasus destruktif dalam pemanfataan sumberdaya laut di wilayah tersebut tidak lagi sepenuhnya dapat diselesaikan melalui mekanisme adat setempat.
Melalui program coremap, Pemerintah Kabupaten Buton pernah menetapkan sejumlah kawasan laut di Wabula sebagai Daerah Perlindungan Laut (DPL). Penetapan DPL, meski awalnya dirasakan manfaatnya oleh masyarakat lokal, bukan tidak menyisahkan masalah. Selama berlangsunya program tersebut, biaya operasional pengawasan DPL bersumber dari coremap. Namun, setelah program ini berakhir tahun 2010, biaya operasional pengawasan DPL juga berakhir. Kondisi ini menyebabkan aktifitas pengawasan DPL oleh petugas pemerintah juga terhenti.

Akibatnya, eksploitasi sumberdaya laut dalam kawasan DPL, baik yang dilakukan nelayan lokal maupun nelayan dari luar Wabula, berlangsung tanpa pengawasan. Bahkan, menurut sejumlah informan, nelayan dari luar Buton bahkan dari luar Sulawesi Tenggara juga sering didapati melakukan eksploitasi sumberdaya laut dalam DPL dengan teknologi yang tidak ramah lingkungan. Sejumlah informan menceritakan, bahwa penanganan kasus-kasus destruktif seperti ini oleh penegak hukum juga tidak berjalan maksimal. Pada sisi lain, masyarakat lokal, melalui dewan adat setempat, tidak memiliki kewenangan menjatuhkan sanksi adat mengingat kawasan DPL berada dalam pengelolaan pemerintah.

\section{Mewujudkan Pengelolaan Sumberdaya Laut Wabula Berbasis Hukum Adat Setempat}

Mengingat pentingnya kelestarian lingkungan laut Wabula sebagai sumber kehidupan masyarakat setempat, maka setelah program coremap berakhir tahun 2010, mengemuka gagasan untuk 
merevitalisasi kearifan lokal tradisional setempat sebagai orientasi dalam pemanfataan sumberdaya laut. Gagasan tersebut antara lain diwujudkan melalui pembentukan Peraturan Desa (PERDES). Namun, hingga tahun 2018, di antara tujuh desa di Kecamatan Wabula hanya satu desa yang menetapkan PERDES dimaksud.

Bertolak dari fenomena itu, maka untuk memaksimalkan perlindungan dan pemanfataan sumberdaya laut Wabula secara berkelanjutan melalui pelibatan langsung masyarakat lokal, maka melalui Peraturan Bupati Buton Nomor 13 Tahun 2018, Wabula ditetapkan sebagai Masyarakat Hukum Adat dalam pengelolaan sumberdaya pesisir dan laut berbasis hukum adat setempat. Melalui peraturan tersebut, maka konsep-konsep ekosistem laut, institusi, kepercayaan, nilai-nilai, norma-norma, dan sejumlah praktik tradisional yang sudah terlembaga dalam masyarakat Wabula menjadi orientasi dalam pemanfataan sumberdaya laut di wilayah tersebut. Peraturan Bupati ini menjadi penting dan strategis untuk meminimalisir praktik eksploitasi sumberdaya laut yang cenderung makin destruktif sekaligus mencegah konflik antara nelayan lokal dengan nelayan dari luar Wabula yang kerap terjadi pasca berakhirnya program coremap. Peraturan Bupati ini diidealkan dapat mendorong partisipasi langsung masyarakat lokal dalam pengambilan keputusan terkait pengelolaan sumberdaya laut di Wabula berbasis kearifan lokal setempat.

Selain kawasan kaombo saumuru dan kaombo awaktuu, wilayah Masyarakat Hukum Adat (MHA) Wabula, selaku "wilayahkelolaadat", dalampemanfataan sumberdaya laut juga mencakup "kawasan pemanfaatan tradisional". Kawasan ini menjadi penyangga antara kawasan kaombo saumuru dan kaombo awaktuu. Dalam kawasan pemanfataan tradisional, yang meliputi wilayah pesisir desa se Kecamatan Wabula, eksploitasi sumberdaya laut, hanya boleh dilakukan melalui peralatan tangkap tradisional. Peraturan Bupati ini sekaligus memayungi kewenangan sara (dewan adat setempat) dalam penegakan sanksi adat terhadap pelanggaran yang terjadi di wilayah masyarakat hukum adat Wabula. Sedangkan, terhadap kasus-kasus destruktif pemanfataan sumberdaya laut yang terjadi di luar wilayah kelola masyarakat hukum adat setempat, penanganannya diselesaikan melalui mekanisme hukum positif oleh pemerintah.

\section{PENUTUP}

Penelitian menyimpulkan: sebagai salah satu komunitas masyarakat adat di Buton yang memanfaatkan sumberdaya laut sebagai sumber kehidupan, masyarakat Wabula memiliki kearifan lokal tradisional dalam pemanfaatan sumberdaya laut secara berkelanjutan sebagaimana terefleksi melalui sistem kaombo; (2) intervensi kebijakan pemerintah dalam pengelolaan sumberdaya laut melalui penetapan Daerah Perlindungan Laut (DPL) pada sejumlah kawasan laut di Wabula, yang tidak dibarengi penguatan kelembagaan dan peran serta masyarakat lokal, mengakibatkan tidak maksimalnya upaya perlindungan sumberdaya laut di wilayah tersebut; (3) pengakuan dan perlindungan masyarakat hukum adat Wabula dalam pengelolaan sumberdaya 
pesisir dan laut berbasis hukum adat setempat melalui Peraturan Bupati Buton Nomor 13 Tahun 2018, secara normatif dapat dipandang sebagai model ideal penguatan kelembagaan masyarakat lokal dalam upaya pelestarian sumberdaya lingkungan laut Wabula secara berkelanjutan.

\section{DAFTAR PUSTAKA}

Evawarni, 2017. Pengetahuan Orang Laut tentang Alam di Provinsi Kepulauan Riau, dalam "Dunia Maritim Indonesia; Perspektif Budaya". Makassar: Pustaka Refleksi.

Hanan, Laode Muh. Saleh, 2010. Kajian Strategi Pengelolaan Sumberdaya Laut oleh Masyarakat Adat dalam Kawasan Taman Nasional Wakatobi. "Tesis Magister". Bogor: Sekolah Pasca Sarjana IPB.

Lampe, Munsi, 2008. Kajian Masyarakat Maritim. Makassar. Program Studi Antropologi FISIP Unhas.

Munafi, La Ode Abdul, 2007. Pengelolaan Lingkungan dalam Perspektif Budaya Buton, dalam "Menanam Sebelum Kiamat; Islam, Ekologi, dan Gerakan Lingkungan Hidup", editor Fachruddin M. Mangunjaya dkk. Jakarta: Yayasan Obor Indonesia.

Mustari, Tamar, dkk., 2016. Kajian Kearifan Lokal dalam Pengelolaan Sumberdaya Pesisir di Sepanjang Teluk Kecamatan Wabula, Pasarwajo, dan Wolowa, "Laporan Penelitian". Baubau:
Badan Litbang Kabupaten Buton dan Fakultas Perikanan dan Kelautan Unidayan.

Mustari Tamar, dkk., 2018. Pemanfataan Sumberdaya Alam Pesisir dan Laut di Kecamatan Wabula, "Laporan Penelitian". Baubau: Badan Litbang Kabupaten Buton dan Unidayan.

Neil, Muhammad, 2007. Merajut Kembali Kearifan Lokal Masyarakat Nelayan Desa Appatana Kabupaten Selayar, dalam "Mengungkap Kearifan Lingkungan Sulawesi Selatan". Makassar: PPLH Regional Sulawesi, Papua, dan Maluku, Kementerian Negara LH dan Masagena Press.

Peraturan Bupati Buton Nomor 13 Tahun 2018 tentang Pengakuan dan Perlindungan Masyarakat Hukum Adat Wabula dalam Pengelolaan Sumberdaya Pesisir dan Laut Berbasis Hukum Adat.

Raodah dkk, 2017. Nuansa Kehidupan Nelayan Danau Tempe Kabupaten Wajo. Makassar: Pustaka Refleksi.

Tang, H. Mahmud, 2007. Kearifan Lokal dalam Pengelolaan Lingkungan Laut pada Masyarakat Nelayan Bugis di Desa Madello Kabupaten Barru, dalam "Mengungkap Kearifan Lingkungan Sulawesi Selatan". Makassar: PPLH Regional Sulawesi, Papua, dan Maluku, Kementerian Negara LH dan Masagena Press.

Zahari, Abdul Mulku, 1977. Sejarah dan Adat Fiy Darul Butuni. Jakarta: Proyek Pengembangan Media Kebudayaan Depdikbud. 